\title{
Overall aspects for the evaluation of Portuguese dwellings' quality and sustainability
}

João Pedro Júlio

University of Trás-os-Montes e

Alto Douro, School of Sciences

and Technology, Quinta de

Prados, Portugal,

jpjulio@gmail.com

\author{
Anabela Paiva \\ University of Trás-os-Montes e Alto \\ Douro, School of Sciences and \\ Technology, Quinta de Prados, \\ Portugal, C-MADE laboratory \\ apaiva@utad
}

Caroline Dominguez

University of Trás-os-Montes e Alto

Douro, School of Sciences and

Technology, Quinta de Prados,

Portugal, C-MADE laboratory,

carold@utad.pt
DOI 10.5592/otmcj.2013.1.7

Research paper

\section{Keywords}

Assessment method, Residential buildings,

Dwelling's quality, Sustainability, Portugal
AS HOUSING IS AN ESSENTIAL NEED, A DWELLING SHOULD PROVIDE AN ASSURED QUALITY OF LIFE AND SATISFY THE EXPECTATIONS OF ITS USERS.

As a dwelling is a complex system, the construction of which involves the contribution of various specialists, the evaluation of its quality is a elaborated process.

In the sequence of previous research on quality dwellings assessment methods, the objective of this paper is to present the proposal of an assessment system for the most important aspects of dwellings' quality in Portugal which provides stakeholders with a simple and objective form for assessing the quality level of a dwelling to be designed, built, financed, bought or rented.

After a thorough analysis of methods used to evaluate residential building quality in various countries, the most common elements were identified. This list was submitted to critical evaluation by Portuguese construction specialists, resulting in a final selection of evaluation aspects such as: housing operating costs, proximity to basic infrastructures, energy classification and rainwater reuse systems. 


\section{INTRODUCTION}

Although construction is one of the major economic sectors in Portugal, it presents high levels of inefficiency and does not provide enough information for all its stakeholders, particularly with regard to the quality of construction, and especially for residential buildings.

Portugal has a low rate of per capita income compared to other European countries, although the percentage of people living in their own homes is surprisingly high (76\% in 2001, approximately $20 \%$ above the European average) (CET-ISCTE/IRIC, 2008). In Portugal, home ownership is considered important as family property (Pereira, 2004), and its value is equivalent to several years of household wages. Nevertheless, the purchase of a primary dwelling is usually made with less information than when purchasing lower cost goods.

As housing is an essential human need, it is expected to provide a quality of life which meets the expectations of users and fits a family's lifestyle. Taking into account the objective and subjective aspects of quality, stakeholders in the construction process, including developers, builders, designers and financers, should enable each owner to choose a home which meets their specific needs.

For this reason, various countries have developed and implemented assessment systems that help measure the quality of buildings, in particular the quality of housing (Paiva and Pereira, 2001). This is no longer considered an abstract concept and has become a tangible measurement to provide users with ways to quantify housing quality as a whole and / or of each of the elements that composes it. These systems, along with the rules and laws, allow for more rational decision making when purchasing a home.

Although some proposals have been developed in Portugal, it is only recently that a more focused assessment of aspects of environmental qual- ity began to be applied (LiderA). However, the need for the implementation of a more comprehensive and inclusive quality assessment system remains.

This article presents the results of an investigation that aims to develop a proposal of assessment criteria for evaluating the quality of housing in Portugal, which integrates the most representative Portuguese housing needs. The work to be presented follows previous research on quality (Júlio, J. et al., 2010) dwellings assessment methods, enlarging the scope of the literature reviewed and consolidating the list of aspects to be evaluated. This proposal can be used as a tool to assist stakeholders in the design of residential buildings - which is considered one of the most important phases to improve the building performance (Othman, 2011) -, and to provide a simple and objective form for assessing the quality level of housing to be designed, built, sold, financed, bought or rented.

The research for this work is based on conditions that should be applicable to residential buildings in Portugal, and the need for methods that should be easy to use without becoming overly detailed and complex (Leaman et al., 2010). All aspects should be considered as feasible for objective assessment, avoiding those where evaluation is too subjective.

The methodology was divided into six main phases, already referred by Júlio, J. et al. (2010):

- Analysis of methods and proposals for evaluating the quality of residential buildings, in foreign countries and in Portugal.

- Preparation of a table with all the aspects evaluated by the set of methods analyzed.

- Definition of a rule for the selection of aspects to be assessed, leading to the following:

- The aspects must be present in at least four methods or proposed methods, one of which is from Portuguese studies.
- Aspects were selected that, although not previously respected in the first version, are considered key to the situation in Portugal, including structural and environmental aspects.

> Preparation of an organized list with the selected aspects from the above process.

- Testing the proposed check list together with a team of experts. The discussion of the issues took place through three joint meetings with three experts in the Portuguese construction industry.

> Preparation of the final check list where the suggestions of experts were integrated, after several adjustments in order to be more focused on the problems of construction in Portugal and to avoid being overly long.

\section{Analysis of residential buildings quality assessment methods}

In this section work which has been done in several countries for use in quality assessment methods for buildings along with Portuguese proposals to increase housing quality will be reviewed in order to identify the factors that differentiate and unite them. A summary table of analysis using points of comparison such as the country of origin, voluntary or mandatory use, creation date and evaluation forms is presented.

The Japanese CASBEE-NC “Comprehensive Assessment System for Building Environmental Efficiency" (Institute for Building Environment and Energy Conservation, 2008) has been used since 2001 to evaluate the design of buildings. The aspects range from the interior of a building to its immediate surroundings. Primarily targeting the environmental performance of the building, rewards are given for reducing the environmental impact of construction and intended use. The results are presented through an overall score (CASBEE assessment levels) and it also allows scrutiny of individual marks in 
each major category. It does not consider the financial aspects, and the structural aspects are limited to considering earthquake resistance.

The Singapore CONQUAS "Construction Quality Assessment System" has been used since 1989 (Building and Construction Authority, 2008) and, unlike other methods, is used to assess the quality of workmanship during and after construction of a building. The assessment is based on three main components: structural work, architectural work and mechanical and electrical work. It was created both for developers to set goals for their builders and to evaluate a building after completion. This method is mandatory for all public buildings in Singapore (the only method analyzed where this happens) however, it is optional for private buildings. Results are presented by the percentage of items met in the assessment of a building, and it allows viewing the percentages obtained by major categories.

The LEED-NC “Leadership in Energy and Environmental Design" system was developed in the United States, in 1998 (US Green Building Council, 2005), to assess the environmental performance of buildings as a whole, taking the life cycle into account. It is an internationally recognized green building certification system, which includes a vast inventory of evaluated built-up areas, yet it remains a voluntary system. The final result is presented as an overall assessment level, but unlike CASBEE it does not allow checking the levels of the main categories individually. Just as with CASBEE and CONQUAS, this method is not overly concerned with economic aspects, and also does not address structural aspects.

Like LEED and CASBEE, the Hong Kong BEAM "Building Environmental Assessment Method" created in 2002 (Hong Kong Building Environment Assessment Method Society, 2004), is used to quantify the environmental performance of buildings. It covers all types of buildings; new and existing, residential, commercial, public and industrial. It covers all stages of building construction, emphasizing the importance of air quality and focuses attention on aspects of interior ventilation, cooling systems and natural light. Unlike the others, it includes economic and social concerns. It is a voluntary, private sector initiative. Evaluation is done through credits which are awarded when individual aspects of the evaluation are satisfied. The results are presented in a similar way to LEED, in the form of an overall assessment, not allowing reference to intermediate results.

The Portuguese proposal of a method, Methods of Quality Assessment of Housing Projects and Buildings (Costa, 1995), is based on preliminary work conducted in 1988 by FEUP (Faculty of Engineering, University of Porto) and IST (Technical Superior Institute), which consisted of defining a set of evaluation criteria. This proposal is extensive, and evaluates 112 items divided into two groups of objectives, one related to the efficiency of the construction aspects and the other to the efficient use of space. The result is presented using a global score, and the marks of individual items may be considered. Unlike CASBEE and LEED, it does not evaluate environmental aspects related to the construction site but evaluates the structural quality. This proposal has not been tested.

The proposal of a method entitled Definition and Assessment of Architectural and Housing Quality (Pedro, 2000) is even more extensive than the previous one because it has 375 aspects to evaluate, making its use very cumbersome. It is a multi-criteria assessment method, directed both to Low Cost Housing projects funded by the Office of Housing and Urban Renewal (IHRU), as well as homes not promoted by the government. The presentation of the results obtained after applying this method can be done in three ways: through the value of overall performance in which a result is given by a numerical value that represents the level of overall quality on a scale of o to 3, through an evaluation report, or through a quality profile where the quality levels of all aspects can be verified. This proposal has been tested but not applied.

The LiderA system is a Portuguese method established in 2005 to assess levels of environmental performance of buildings from the perspective of sustainability (LiderA, 2005). It's from the same international family as LEED and CASBEE, with assessment similar to LEED. It is a voluntary rating system that distinguishes projects that build sustainable value. The first five certifications were made in 2007. The LiderA system is divided into six categories of evaluation and their level of performance is presented in the form of percentages. According to the percentage received the project can fit in one of the eight existing classes, from $\mathrm{E}$ to $\mathrm{A}+++$. It does not address structural aspects nor the cost / quality relationship.

The HQI system "Housing Quality Indicator System" in the United Kingdom was created in February 1999 (Housing Corporation, 2007) and aims to assess all homes. It considers three main categories: location, design and environment. These three categories are subdivided into ten quality indicators which are evaluated and classified through a series of questions. The classification identifies the strengths and weaknesses of the assessed housing. Thus, the HQI not only presents its results through an overall score, but also by the level of performance for each indicator.

The BREEAM "Building Research Establishment Environmental Assessment Method" is a method for evaluating environmental performance of buildings, the first to be developed in the UK in the early 1990's (British Research Establishment, 2006, 2008). It allows evaluation of houses, office 


\begin{tabular}{|c|c|c|c|c|c|c|c|c|c|c|}
\hline $\begin{array}{l}\text { Method } \\
\text { Name }\end{array}$ & Country & $\begin{array}{l}\text { Date of } \\
\text { Creation }\end{array}$ & $\begin{array}{l}\text { In } \\
\text { Use }\end{array}$ & $\begin{array}{l}\text { Quality } \\
\text { Profile }\end{array}$ & $\begin{array}{l}\text { Global } \\
\text { Rating }\end{array}$ & $\begin{array}{c}\text { Assessment } \\
\text { of the } \\
\text { Versatility } \\
\text { of Spaces }\end{array}$ & $\begin{array}{l}\text { Assess- } \\
\text { ment of } \\
\text { Site } \\
\text { Location }\end{array}$ & $\begin{array}{l}\text { Assess- } \\
\text { ment of } \\
\text { Construc- } \\
\text { tion }\end{array}$ & $\begin{array}{l}\text { Assess- } \\
\text { ment of } \\
\text { Design }\end{array}$ & $\begin{array}{c}\text { Method } \\
\text { Utilization }\end{array}$ \\
\hline CASBEE - NC & Japan & 2002 & Yes & Yes & Yes & Yes & Yes & No & Yes & $\begin{array}{l}\text { More than } 1000 \\
\text { registrations } \\
\text { / more than } \\
20 \text { certified } \\
\text { buildings }\end{array}$ \\
\hline CONQUAS & Singapore & 1989 & Yes & No & Yes & No & No & Yes & No & $\begin{array}{c}\text { More than } 2200 \\
\text { developments } \\
\text { evaluated }\end{array}$ \\
\hline LEED - NC & USA & 1998 & Yes & No & Yes & Yes & Yes & Yes & Yes & $\begin{array}{c}\text { More than } \\
900,000 \text { million } \\
\text { square meters of } \\
\text { area certified }\end{array}$ \\
\hline HK-BEAM & $\begin{array}{l}\text { Hong } \\
\text { Kong }\end{array}$ & 1996 & Yes & No & Yes & No & Yes & Yes & Yes & $\begin{array}{l}70 \% \text { of private } \\
\text { buildings and } \\
30 \% \text { of public } \\
\text { buildings } \\
\text { assessed }\end{array}$ \\
\hline AMQD & Portugal & 1995 & No & Yes & Yes & No & No & No & Yes & $\begin{array}{l}\text { Needs to be } \\
\text { tested }\end{array}$ \\
\hline DEAQH & Portugal & 2000 & No & Yes & Yes & Yes & Yes & No & Yes & $\begin{array}{c}\text { Has already been } \\
\text { tested, } \\
\text { but was not } \\
\text { implemented }\end{array}$ \\
\hline Líder A & Portugal & 2005 & Yes & No & Yes & No & Yes & Yes & Yes & $\begin{array}{c}\text { More than } \\
330,000 \\
\text { m2 of gross } \\
\text { construction } \\
\text { area assessed }\end{array}$ \\
\hline Qualitel & France & 1974 & Yes & Yes & No & No & No & $\begin{array}{c}\text { By } \\
\text { sampling }\end{array}$ & Yes & $\begin{array}{l}\text { More than } \\
\text { 1.5 million of } \\
\text { dwellings }\end{array}$ \\
\hline HQI & UK & 1996 & Yes & Yes & Yes & Yes & Yes & No & Yes & $\begin{array}{l}\text { Without } \\
\text { information }\end{array}$ \\
\hline BREEAM & UK & $\begin{array}{c}1990 \\
\text { decade }\end{array}$ & Yes & Yes & Yes & No & Yes & No & Yes & $\begin{array}{l}700,000 \\
\text { registered } \\
\text { projects }\end{array}$ \\
\hline SEL & $\begin{array}{l}\text { Switzer- } \\
\text { land }\end{array}$ & 1975 & Yes & Yes & Yes & Yes & Yes & No & Yes & $\begin{array}{l}\text { About } 20,000 \\
\text { dwellings until } \\
2001\end{array}$ \\
\hline
\end{tabular}


buildings, industrial plants, commercial buildings and other types of buildings. It promotes buildings with less environmental impact, both in terms of resource consumption and emissions. The BREEAM method is divided into eight categories of evaluation: Energy, Health and wellness, Land use and ecology, Materials, Pollution, Water, Transport and maintenance. Each category is divided into subcategories, assessed by the awarding of credits, which are variable according to their relative importance. Assessment is quite similar to other methods studied, based on the allocation of credits. The set of credits achieved allows the environmental performance index of the building to be obtained.

Created in 1974 in France, the Qualitel method aims to improve the quality of designs and enhance the performance of technicians (Association Qualitel, 2008). To be awarded a Qualitel certification it is necessary to subject the housing to evaluation under seven mandatory headings (exterior acoustic, interior acoustics, thermal behavior in the summer and in winter, sanitary facilities, design and durability involving economic issues) by Qualitel Association examiners. There is an optional item, Accessibility and Habitability (AH). Each item of assessment is divided into several sub-headings, each of these being assessed on a scale of 1 to 5 . It takes a minimum grade of 3 in all categories to obtain a Qualitel housing certification. Whenever a sub-heading has a low score, the top item in the evaluation tree is strongly penalized. This is applied with the intention of favoring the homogeneity of designs.

The SEL “Systeme d'Evaluation de Logements" method is a result of work done in the 6o's by the Office Fédéral du Logement in Switzerland (Office Fédéral du Logement, 2000). It was first applied in 1975 with the aim of supporting a federal law that encouraged the purchase of private housing at moderate cost with higher quality. Its main objective is to establish the relationship between the cost and quality of housing, so that federal funds used to purchase housing at moderate cost would be well spent. It is aimed at designers, master-builders, real estate specialists and economic experts. The current version of the SEL evaluates 39 criteria divided into three groups: Housing (W1), Outdoor Surroundings (W2) and Local Implementation $\left(W_{3}\right)$. The end result of this method is presented in the form of a quality profile with an overall score.

Through the analysis of Table 1 which presents a summary of the studied methods, it can be concluded that most methods are local except for the LEED application. Seven of the 11 methods provide the quality profile of a building as well as an overall score. Only one does not have an overall score. The evaluation of a design is the main form of analysis of these methods with the exception of the CONQUAS, which only evaluates the construction phase. They are all on a voluntary basis except in CONQUAS, where the assessment of public buildings is mandatory. The Portuguese methods and proposals of methods are the least used, one has never been tested. Almost all of the methods discussed are national in scope with the exception of LEED which is spread worldwide; however, this does not detract from the merit of their function as regulators of quality.

\section{Proposal of assessment aspects for Portuguese residential buildings}

After a review of the methods and according to the methodology, a table that brings together the different aspects in areas of assessment used has been created (Table 2). None of the methods, presented in Table 2, covers all aspects. This is due to the fact that they have been developed within the conditions of their respective country of origin and also in accordance with specific goals. The international family of the same methods (LEED, CASBEE, BEAM, and LiderA) covers much the same areas of evaluation, giving a lot of emphasis to environmental aspects. SEL and CONQUAS are devoted to different evaluation areas than the other methods, and are seen to have very few areas in common with the array of methods analyzed.

Subsequent to the construction and analysis of Table 2, and following the methodology specified in the Introduction, aspects were grouped and compared in order to choose those which were present in at least four of the methods, one of which Portuguese. The issues arising from the selection were arranged in an assessment list which was discussed with experts in this field over several joint meetings. The experts suggested integrating some assessment areas which had not been included in the previous selection. This addition aimed to introduce aspects more specific to the Portuguese conditions, including construction characteristics and construction materials. The importance of this last category is largely discussed by Porhincak and Estokova (2011). The final result is shown in Figure 1.

These aspects are organized into seven categories (aspects of the location, indoor environment, materials, energy use, water use, construction and economic aspects), each subdivided into several areas of evaluation for a total of 18 . These in turn were subdivided into a total of 40 evaluation aspects.

For a better understanding of this proposal and its possible future practical application, it is essential to define each of the aspects to be evaluated. The definitions presented here result from a combination of different methods and expert opinions.

Proximity to basic infrastructure: Choice of Building / Housing construction site in relation to proximity 


\begin{tabular}{|c|c|c|c|c|c|c|c|c|c|c|c|c|}
\hline 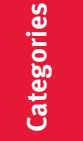 & $\begin{array}{l}\text { Methods of } \\
\text { Evaluation }\end{array}$ & ¿ & 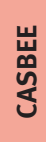 & $\begin{array}{l}\sum_{\infty} \\
\dot{⿱ ㇒ ⿲ 丶 丶 ㇒} \\
\dot{I}\end{array}$ & $\frac{\vec{z}}{\underline{\underline{E}}}$ & $\frac{n}{8}$ & 모 & 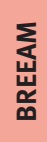 & 嵌 & $\sum_{<}^{0}$ & $\sum_{\frac{1}{0}}^{\frac{1}{0}}$ & 는 \\
\hline \multirow{7}{*}{ 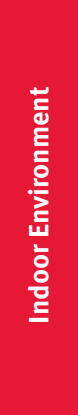 } & Safety & - & - & $X$ & - & - & - & - & - & $X$ & $X$ & - \\
\hline & Hygiene & - & - & $x$ & - & - & - & - & - & $X$ & - & - \\
\hline & Indoor Air Quality & $\mathrm{X}$ & $\mathrm{X}$ & $\mathrm{X}$ & - & - & $\mathrm{X}$ & - & $\mathrm{X}$ & - & $\mathrm{X}$ & $\mathrm{X}$ \\
\hline & Thermal Comfort & $\mathrm{X}$ & $X$ & $X$ & $\mathrm{X}$ & - & - & - & - & $X$ & $X$ & $x$ \\
\hline & Lighting Quality & $X$ & $X$ & $X$ & - & - & $\mathrm{X}$ & $\mathrm{X}$ & $x$ & $\mathrm{X}$ & $x$ & $x$ \\
\hline & Acoustics and Noise & - & $X$ & $\mathrm{X}$ & $\mathrm{X}$ & - & $X$ & $X$ & $X$ & $\mathrm{X}$ & $X$ & $x$ \\
\hline & Building Amenities & - & $x$ & $x$ & $x$ & - & - & - & - & - & - & $x$ \\
\hline \multirow{5}{*}{ 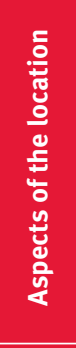 } & Site Location & $\mathrm{X}$ & $\mathrm{X}$ & $\mathrm{X}$ & - & - & - & $X$ & $X$ & - & - & $x$ \\
\hline & $\begin{array}{l}\text { Considerations of } \\
\text { the Surrounding } \\
\text { Environment }\end{array}$ & - & $X$ & $\mathrm{X}$ & - & - & $X$ & - & - & - & $X$ & $x$ \\
\hline & $\begin{array}{l}\text { Landscape } \\
\text { Surroundings }\end{array}$ & $\mathrm{X}$ & $\mathrm{X}$ & $\mathrm{X}$ & - & - & - & $x$ & - & - & $x$ & $\mathrm{X}$ \\
\hline & $\begin{array}{c}\text { Preservation \& Creation } \\
\text { of Biotype }\end{array}$ & $\mathrm{X}$ & $X$ & $\mathrm{X}$ & - & - & - & - & - & - & - & - \\
\hline & $\begin{array}{c}\text { Considerations of the } \\
\text { Local Environment }\end{array}$ & $x$ & $x$ & $x$ & - & - & - & - & - & - & - & $x$ \\
\hline \multirow{4}{*}{$\frac{\frac{n}{70}}{\frac{\pi}{\frac{\pi}{2}}}$} & Selection of Materials & $\mathrm{X}$ & $\mathrm{X}$ & $X$ & $\mathrm{X}$ & - & - & $X$ & - & - & - & $X$ \\
\hline & Waste Management & $X$ & - & $X$ & - & - & - & - & - & - & - & $x$ \\
\hline & $\begin{array}{c}\text { Efficient use of } \\
\text { Materials }\end{array}$ & - & - & $X$ & - & - & - & - & - & - & - & - \\
\hline & $\begin{array}{l}\text { Avoiding the Use } \\
\text { of Materials with } \\
\text { Pollutants Content }\end{array}$ & $X$ & $X$ & $X$ & - & - & - & - & - & - & - & $x$ \\
\hline \multirow{6}{*}{ 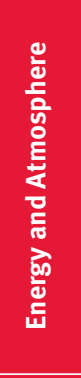 } & Use of Natural Energy & $\mathrm{X}$ & $\mathrm{X}$ & $x$ & & - & - & $\mathrm{X}$ & - & - & - & $x$ \\
\hline & Facilities for Energy & - & - & $X$ & - & - & - & - & - & - & - & \\
\hline & $\begin{array}{l}\text { Energy Efficient } \\
\text { Systems }\end{array}$ & - & $X$ & $X$ & - & - & - & - & - & - & - & $X$ \\
\hline & Building Thermal Load & $X$ & $X$ & - & - & - & - & - & - & - & - & $\mathrm{x}$ \\
\hline & $\begin{array}{c}\text { Management of Energy } \\
\text { Use }\end{array}$ & $\mathrm{X}$ & $x$ & $X$ & - & - & - & $x$ & - & - & - & $\mathrm{X}$ \\
\hline & $\begin{array}{c}\text { Considerations about } \\
\text { Global Warming }\end{array}$ & $\mathrm{X}$ & $\mathrm{X}$ & $x$ & & - & - & - & - & - & - & $x$ \\
\hline \multirow{5}{*}{\begin{tabular}{l}
$\stackrel{8}{3}$ \\
$\frac{2}{3}$ \\
\multirow{3}{3}{}
\end{tabular}} & Water Quality & - & - & $X$ & - & - & - & $x$ & - & - & - & $\mathrm{X}$ \\
\hline & Effluent & - & - & $x$ & - & - & - & - & - & $x$ & - & $x$ \\
\hline & Water Conservation & $x$ & - & $x$ & - & - & - & - & - & - & - & $\mathrm{x}$ \\
\hline & Water Saving & $x$ & $x$ & $x$ & - & - & - & - & - & - & - & $\mathrm{x}$ \\
\hline & $\begin{array}{c}\text { Rainwater water and } \\
\text { Gray water }\end{array}$ & $X$ & $\mathrm{X}$ & $\mathrm{X}$ & - & - & - & - & - & $x$ & - & $x$ \\
\hline \multirow{3}{*}{ 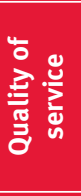 } & $\begin{array}{l}\text { Qualifications of the } \\
\text { Service }\end{array}$ & - & $\mathrm{X}$ & - & - & - & - & - & - & - & $x$ & \\
\hline & Durability \& Reliability & - & $X$ & - & - & - & - & - & - & - & $x$ & $x$ \\
\hline & $\begin{array}{c}\text { Flexibility and } \\
\text { Adaptability }\end{array}$ & - & $x$ & - & - & - & - & - & - & - & $x$ & $x$ \\
\hline \multirow{2}{*}{ 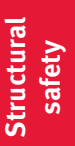 } & Foundations & - & - & - & - & - & - & - & - & $X$ & - & - \\
\hline & Superstructure & - & - & - & - & - & - & - & - & $X$ & - & - \\
\hline
\end{tabular}




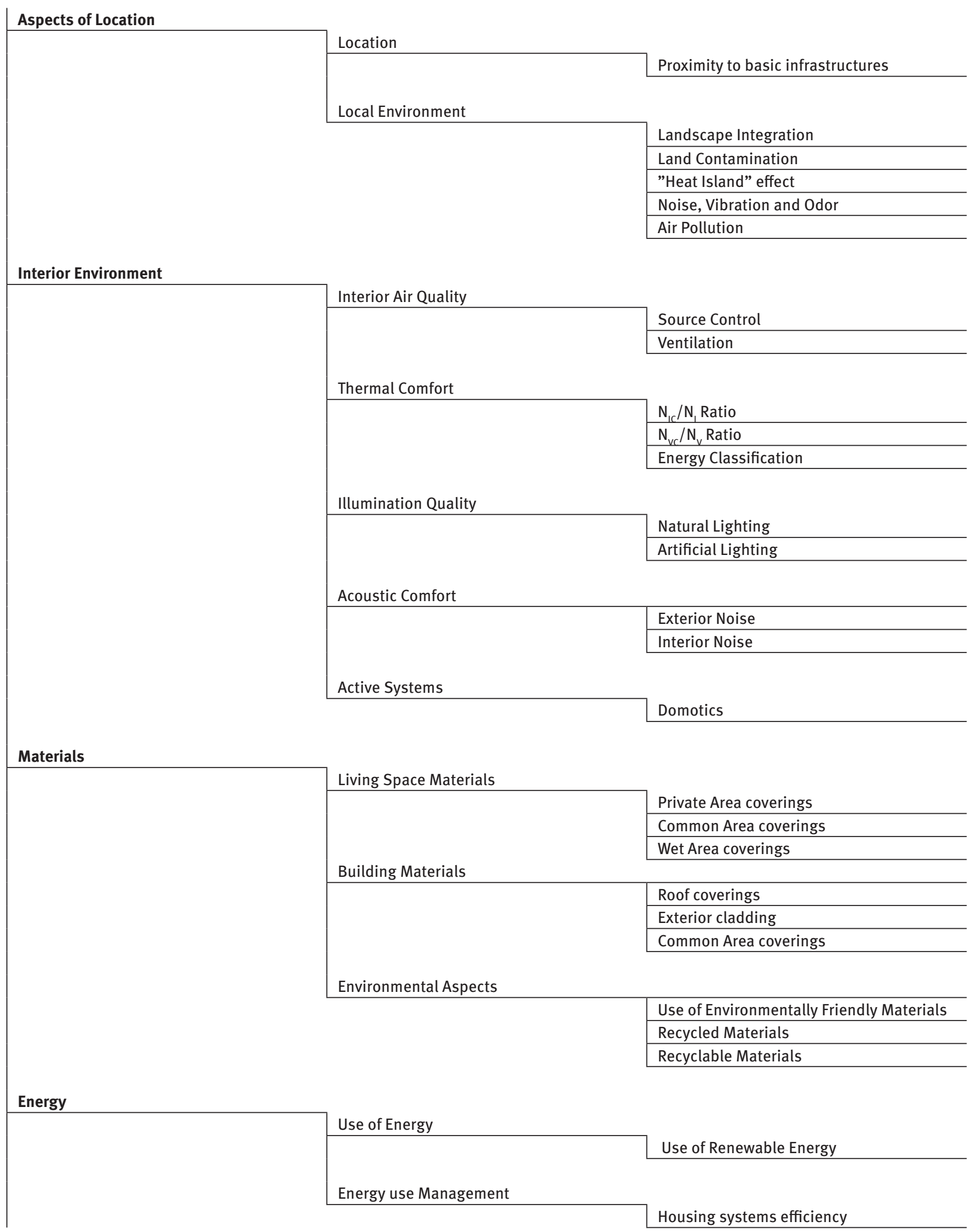




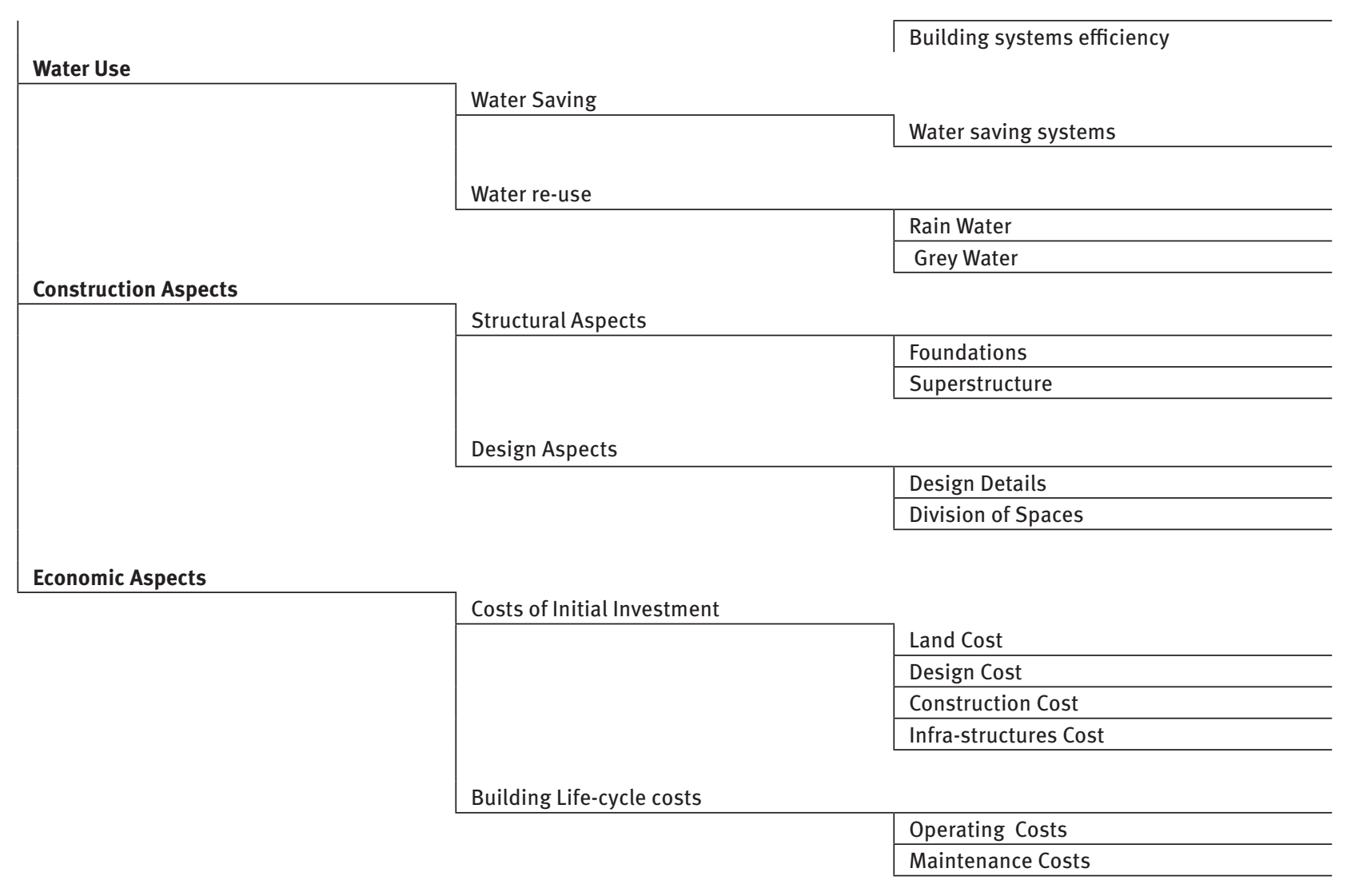

Figure 1 Proposed final assessment aspects of Portuguese housing

to infrastructures such as schools, public transport, public parks, major access routes, services and centers of culture. There should also be parking spaces nearby.

Landscape integration: The building should be integrated as an asset to the neighborhood. The visual impact of the implementation of a structure on a site should be mitigated to harmonize with the Building / Housing in the locale.

Land Contamination: Ensures an appropriate investigation and resolution of potential pollution from the construction site during construction, or provide for adoption of preventive measures affecting locales adjacent to the construction site.

"Heat island" Effect: A "heat island" effect is caused by a set of physical reactions, which include urban surfaces (roads, building, etc.) that absorb the heat of solar radiation, thereby warming and increasing the local temperature. These effects may be miti- gated through the use of appropriate materials, including light colors, green roofs or other solutions.

Noise, Vibration and Odor: Noise, vibration and odors from the building / housing that could harm the neighborhood should be avoided or mitigated in the project.

Air Pollution: The statutory requirements for reducing emissions of potentially acidifying substances (emission of $\mathrm{SO}_{2}$ - sulfur oxides, and NO - nitrogen oxides) must be observed. It is essential to ensure the reduction of $\mathrm{CO}_{2}$ emissions (associated with burning and other activities), as well as the elimination of emissions of CFCs.

Source Control: Preventing pollution at the source is the most effective way to maintain a healthy indoor environment. Thus, it is important to control the quality of the air entering the building/housing.

Ventilation: Ensure that the ventilation system works properly, taking into account the energy class of devices to ensure well-being and comfort in normally occupied spaces.

NIC/NI Ratio: The regulatory relationship Nic $\leq \mathrm{Ni}$ must be complied. Through this relationship the quality of the elements of the building envelope under winter conditions can be verified.

NVC/NV Ratio: The regulatory relationship Nvc $\leq \mathrm{Nv}$ must be complied. Through this relationship the quality of the elements of the building envelope under winter conditions can be verified.

Energy Class: The energy class of housing should be within the range applicable to new buildings. The better the class of housing the greater the energy efficiency, therefore it gets a higher ranking.

Natural Lighting: The introduction of natural light should be considered in the design to promote its use and to benefit the users of the building / housing. 
Artificial Lighting: The lighting levels of the building must take into account the activities in each area and the occupants characteristics.

Exterior Noise: Noise from outside of the building / housing should be avoided or mitigated in the project.

Interior Noise: Noise coming from inside the building (common areas, equipment, etc.) or transmitted between living areas should be avoided or mitigated in the project. Domotics: The use of active systems (in the areas of automation, lighting, air conditioning, security and communication) should be encouraged in order to provide a better quality of life for users.

Private Area Coverings: The coverings of walls, floors and ceilings must be made of certified materials and of ensured suitability for use, without limiting aesthetic design solutions. Common Area Coatings: The coatings of walls, floors and ceilings must be made of certified materials and of ensured suitability for use, without limiting aesthetic design solutions.

Wet Area Coatings: The materials used in wet areas, walls, floors and ceilings must be made of material certified suitable for humid environments.

Roof Coverings: The roof covering materials used in building / housing should ensure durability and maintenance of their original appearance without the need for frequent intervention.

Exterior Cladding: The materials used in the cladding of facades should ensure durability and maintenance of their original appearance without the need for frequent intervention.

Common Area Coverings: The covering of walls, floors and ceilings must be made of certified materials and of ensured suitability for use, without limiting aesthetic design solutions.

Use of Materials without Hazardous Substances: Analyzes the reduced use of chemicals that can not only affect indoor air quality but are potentially harmful to the general environment.
Recycled Materials: Promotes the use of recycled materials to reduce the consumption of limited resources.

Recycling: Promotes the use of recyclable materials, so they can be reused after the demolition of the building.

Use of Renewable Energy: Photovoltaic panels, solar collectors and other methods for converting natural energy into electricity or heat should be assessed as renewable energy use.

Housing Systems Efficiency: Ensures efficient lighting and where possible control the energy saving in order to ensure the welfare and safety of the housing users.

Building Systems Efficiency: Ensures efficient lighting and where possible control the energy saving control to ensure the welfare and safety of users of common areas of the building.

Water Rationalization Systems: Evaluates water saving methods and equipment installed in the water supply of the building / housing.

Rainwater: Evaluates the measures undertaken to promote reuse of rainwater in the building / housing.

Gray Water: Evaluates the measures taken to promote the reuse of gray water in the building / housing.

Foundations: Evaluates the geotechnical information, the design and detailing.

Super-structure: Evaluates the structural design, the actions, its design and detailing.

Design details: The design must be drafted with the necessary details so that no doubts arise, both in the building work and in subsequent revisions of adopted solutions.

Division of Space: The division of space in the project should include an organization of space so that the arrangement of rooms is as practical as possible.

Land Cost: The cost of the land should be defined so that it can be related to the average price in an area.

Infrastructures Cost: The cost of the building infrastructures should be foreseen in the original design.
Design Cost: The design costs should be listed so that they can be compared with the fees normally paid for the same type of construction.

Construction Cost: Construction cost should be defined in the design and differentiated in such a way as to avoid possible increases in the cost initially predicted.

Operating Costs: Operating costs of the building / housing should be taken into account in the design phase and should be available to users as a deciding factor in the acquisition of the property.

Maintenance costs: Maintenance costs of the building / housing should be taken into account in the design phase and should be available to users as a deciding factor in the acquisition of the property.

In order to complete and implement the assessment method it is necessary to develop evaluation forms for each aspect.

\section{DISCUSSION AND CONCLUSIONS}

After a review and comparison of different quality and sustainability assessment methods worldwide, this paper presents a proposal for Portugal of a tool to assist stakeholders in the design of residential buildings and to provide a simple and objective form for assessing the quality level of housing to be designed, built, sold, financed, bought or rented.

The proposed list of aspects for residential buildings in Portugal consists of forty evaluation aspects covering the following categories: location, indoor environment, materials, energy, water use, construction aspects and economics. This can constantly evolve according to the innovations of the industry, and by updating the issues.

The proposed aspects may be improved through more extensive tests with specialists in this sector.

In future work it is necessary to com- 
plete this proposal through the development of evaluation forms for all the aspects mentioned, defining specific evaluation processes and their weighing.

\section{References}

Association Qualitel (2008), “Référentiel Millésime”, available at: http://www.qualitelogement.org/documentation/referentiels. html?return_url=312 (accessed February 2011).

Building and Construction Authority (BCA) (2008), "Construction Quality Assessment System, Seventh Edition”, available at: http://www.bca.gov.sg/professionals/ iquas/conquas_abt.html (accessed February 2011).

British Research Establishment (2006), "BREEAM

- Ecohomes 2006 - The environmental rating for homes. The Guidance 2006", Issue1.2., April 2006, available at: http://www.breeam. org/filelibrary/Technical\%2oManuals/ EcoHomes_2006_Guidance_v1.2_-April_2006.pdf (accessed February 2011).

British Research Establishment (2008), “BRE Environmental \& Sustainability Standard, Pilot Program - Draft: Issue v1.o", BREEAM Communities, available at: http://www. breeam.org (accessed Feb. 2008).

CET-ISCTE/IRIC (2008), Diagnóstico e proposta para uma estratégia de habitação 2008/2013, University of Porto/A. Mateus Associados Portugal, Portugal.

Costa, J. M. (1995), Métodos de avaliação da qualidade de projectos de edifícios de habitação, PhD Thesis, FEUP, Porto, Portugal.

Hong Kong Building Environment Assessment Method Society (HK-BEAM) (2004), "HK-BEAM 4/o4 New Buildings”, available at: http:// www.beamsociety.org.hk/files/_4-04\%20 New\%2oBuildings\%2o(Full\%2oVersion).pdf (accessed February 2011).

Housing Corporation (2007), Housing Quality Indicators, Version 4 (For NAHP 08-10), HQI, UK.

Institute for Building Environment and Energy Conservation (IBEC) (2008), “CASBEE for New Construction”, Technical Manual, 2008 Edition, available at: http://www.ibec.or.jp/ CASBEE/english/download.htm (accessed February. 2011).
Júlio, J., Paiva, A and Dominguez, C. (2010), "A Contribution to the Development of a Method for Assessing the Quality of Projects for Residential Buildings", in proceedings (in digital format) of the 37은 IAHS World Congress in Housing Science 2010, Santander, Spain, Abstracts published by Uktay Ural, pp. 290.

Leaman, A., Stevenson, F. and Bordass, B. (2010), “Building Evaluation: Practice and Principles", Building Research and Information, 38(5): 564-577. [Taylor and Francis Online].

LiderA (2005), "Sistema LiderA", available at: http://www.lidera.info (accessed April 2011).

Office Fédéral du Logement (OFL) (2000), System d'Evaluation des Logements SEL, Bern, Suisse, available at: http:// www.bwo.admin.ch/wbs/00213/index. html?lang=fr (accessed February 2011).

Othman, A. (2011), “Improving Building Performance through Integrating Constructability in the Design Process", OTMC), 3(2): 333-347. DOI 10.5592/ otmcj.2011.2.6

Paiva, A. and Pereira, S. (2001), Métodos de Avaliação da Qualidade de Edifícios de Habitação, Publication of Observatório da Construção, UTAD, Vila Real, Portugal.

Pedro, J. B. (2000), Definição e Avaliação da Qualidade Arquitectónica da Qualidade Habitacional, PhD Thesis, Faculdade de Arquitectura da Universidade do Porto, Porto, Portugal.

Pereira, S. (2004), Levantamento dos principais aspectos que influenciam a qualidade dos edifícios de habitação em TMAD, MSc Thesis, UTAD, Vila Real, Portugal.

Porhincák, M. and Eštoková, A. (2011), "Environmental Profile of Building Materials of a Single Family House", OTMC), 3(2): 348-353, DOI 10.5592/otmcj.2011.2.7

United States Green Building Council (2005), "LEED for New Construction \& Major Renovations", version 2.2, available at: http://www.usgbc.org/ShowFile. aspx?DocumentID=1095 (accessed February 2011). 